\title{
ANALISIS STRUCTURE CONDUCT PERFORMANCE PADA PEMASARAN KOMODITAS TOMAT DI KABUPATEN GARUT
}

\section{STRUCTURE CONDUCT PERFORMANCE ANALYSIS ON THE MARKETING OF TOMATO COMMODITIES IN GARUT}

\author{
Fitri Awaliyah*, Vela Rostwentivaivi \\ Fakultas Pertanian Universitas Garut, Jl. Raya Samarang No. 52 Garut, 44151 \\ *E-mail: fitriawaliyah@uniga.ac.id \\ (Diterima 5-12-2020; Disetujui 2-1-2021)
}

\begin{abstract}
ABSTRAK
Kabupaten Garut saat ini mempunyai posisi sebagai produsen tomat tersebsar di Jawa Barat. Besarnya jumlah produksi tomat mendorong adanya pemasaran yang cukup luas yang banyak melibatkan peran pelaku pemasaran. Penelitian ini bertujuan untuk mengetahui struktur pasar, perilaku pelaku pemasaran, serta kinerja pemasaran komoditas tomat di Kabupaten Garut. Penelitian ini dilakukan di 4 kecamatan dengan produksi tomat terbesar di kabupaten Garut, yaitu Cikajang, Cisurupan, Cigedug dan Paisrwangi. Sampel yang diambil dalam peneltian ini sebanyak 40 petani dan menelusuri pemasaran tomat dengan teknik snowball sampling. Metode analisis data yang digunakan adalah analisis konsentrasi pasar, analisis minimum efficiency scale, analisis kualitatif deskriptif perilaku pasar, serta analisis margin pemasaran dan farmer's share. Hasil penelitian menunjukkan bahwa rasio penjualan 8 pedagang tomat besar terkonsentrasi lemah yang mengarah pada persaingan monopolistik. Terdapat hambatan masuk pasar komoditas tomat ini. Perilaku pasar menunjukkan, aktivitas pemasaran paling banyak dilakukan adalah aktivitas jual, beli, angkut dan pemanfaatan informasi harga sesama pelaku pemasaran. Aktivitas sortasi dan grading mayoritas hanya dilakukan oleh para pedagang pengumpul dan besar. Penangana resiko pemasaran terbesar terjadi di petani dan pedagang pengecer. Analisis margin pemasaran memperlihatkan, margin pemasaran tertinggi terjadi ketika tomat dijual untuk tujuan pasar luar pulau, dan margin pemasaran terendah terjadi ketika tomat dipasarkan untuk tujuan kebutuhan industri. Hasil analisis farmer's share menunjukkan, share tertinggi yang diterima petani adalah ketika menjual tomatnya untuk kebutuhan industri, hal ini terjadi karena pendeknya rantai pemasaran dan harga jual untuk industri bersifat kontrak di atas harga pasar.
\end{abstract}

Kata kunci: sturktur, perilaku, kinerja, pemasaran, tomat

\begin{abstract}
Garut Regency currently has the position as the largest tomato producer in West Java. The large amount of tomato production encourages a fairly broad marketing that involves a lot of marketing actors. This study aims to determine the market structure, the behavior of marketing actors, and the performance of the tomato commodity market in Garut Regency. This research was conducted in 4 districts with the largest tomato production in Garut district, namely Cikajang, Cisurupan, Cigedug and Paisrwangi. The samples taken in this research were 40 farmers and tracked the marketing of tomatoes using the snowball sampling technique. The data analysis methods used are market concentration analysis, minimum scale efficiency analysis, descriptive qualitative analysis of market behavior, and marketing margin analysis and farmer's share. The results showed that the sales ratio of 8 large tomato traders was weakly concentrated which led to monopolistic competition. There are barriers to entry to this tomato commodity market. Market behavior shows that most marketing activities are selling, buying, transporting and utilizing price information among marketing actors. The majority of the sorting and grading activities are only carried out by collector trader and wholesaler. The greatest marketing risk management occurs in farmers and retailers. Marketing margin analysis shows that the highest marketing margin occurs when
\end{abstract}


tomatoes are sold for market destinations outside the island, and the lowest marketing margin occurs when tomatoes are marketed for industrial purposes. The results of farmer's share analysis show that the highest share received by farmers is when selling tomatoes for industrial needs, this happens because of the short marketing chain and the selling price for the industry is contractually above the market price.

Keywords: structure, conduct, performance, marketing, tomatoes

\section{PENDAHULUAN}

Komoditas tomat pada tahun 2015 menjadi pemberitaan ketika petani tomat di Kabupaten Garut membuang hasil panennya karena harga dinilai sangat rendah, yaitu mencapai $\mathrm{Rp} 200$ per $\mathrm{kg}$ (BPS, 2016). Harga tomat tahun 2016 meningkat menjadi Rp 20.000 per $\mathrm{kg}$ karena terjadinya gagal panen di tingkat petani (Oke Finance, 2016). Tahun 20172019 harga tomat mengalami fluktuasi yang disebabkan beberapa faktor, seperti serangan hama, penyakit, dan cuaca yang tidak menentu. Harga tomat di tingkat konsumen juga mengalami fluktuasi ketika menghadapi hari raya maupun awal tahun. Tomat bukanlah komoditas unggulan secara nasional, namun komoditas ini belum mendapatkan perlindungan harga dari pemerintah (Marina \& Dety, 2017). Fluktuasi harga mengindikasikan berbagai faktor, diantaranya produksi tomat yang masih terkonsentrasi pada daerah tertentu, ketidaksesuaian pola produksi, tidak memadainya fasilitas produksi serta pemasaran, dan panjangnya rantai pemasaran (Irawan, 2007).

Secara nasional pasokan tomat 27,48 persen berasal dari Provinsi Jawa Barat (BPS, 2018), dan Kabupaten Garut mempunyai posisi sebagai produsen tomat terbesar di Jawa Barat dengan kapasitas produksi hingga 11.051 ton dan menyumbang 57,9 persen dari keseluruhan pasokan di tomat di Provinsi Jawa Barat (BPS, 2016). Besarnya jumlah produksi tomat di Kabupaten Garut mendorong adanya pemasaran dan pendistribusian tomat tidak hanya untuk memenuhi kebutuhan lokal, namun juga untuk memenuhi kebutuhan nasional di beberapa daerah pusat konsumsi dan kebutuhan luar pulau yang tidak mampu memproduksi tomat secara mandiri. Adanya kegiatan pemasaran tomat tersebut banyak melibatkan peran pelaku pemasaran dari mulai petani, pedagang pengumpul, pedagang besar, pedagang ecer hingga konsumen tomat itu sendiri.

Harga tomat di pasaran ditentukan oleh 3 (tiga) hal yang saling terkait satu sama lain, yaitu struktur, perilaku, dan 
kinerja pemasaran. Struktur pasar yang terbentuk akan menentukan sistem penetapan harga, jika produsen memiliki market power yang cukup besar maka dengan mudah dapat mempengaruhi harga. Salah satu upaya untuk mengatasi permasalahan di dalam sistem pemasaran yaitu dengan menganalisis sistem pemasaran menggunakan pendekatan struktur pasar (market stucture), perilaku pasar (market conduct) dan kinerja pasar (market performance) (Jaya, 2001).

\section{METODE PENELITIAN}

Penelitian ini dilaksanakan pada bulan April - November 2020. Tempat penelitian dipilih secara purposive yaitu di 4 Kecamatan di Kabupaten Garut antara lain di Kecamatan Cikajang, Cigedug, Cisurupan dan Pasirwangi. Pemilihan lokasi tersebut atas pertimbangan karena merupakan sentra produksi tomat terbesar di Kabupaten Garut. Teknik pengumpulan data dilakukan dengant teknik wawancara terhadap 40 petani tomat yang ditentukan secara purposive (sengaja). Data petani yang digunakan adalah data cross section yang diambil dari data yang bersumber dari petani yang menanam tanaman tomat terakhir pada tahun 2019. Teknik pengambilan sampel pelaku pemasaran dilakukan dengan teknik snowball sampling.

Metode analisis data dalam penelitian menggunakan metode sebagai berikut:

\section{Analisis Struktur Pasar}

1. Konsentrasi Pasar

Konsentrasi pasar dapat dihitung dengan CR 8 (Eight Firm Concentration Ratio) yang merupakan metode dengan tujuan untuk melihat pangsa pasar 8 pedagang besar di Kabupaten Garut. Perhitungan nilai ini digunakan rumus sebagai berikut:

$$
C R_{8}=\frac{S_{1}+S_{2}+S_{3}+\cdots \ldots+S_{n}}{S T}
$$

$\mathrm{CR} 8=$ Konsentrasi rasio

$\mathrm{S} 1=$ Volume penjualan tomat oleh pedagang besar 1 (ton/tahun)

$\mathrm{Sn}=$ Volume penjualan tomat oleh pedagang besar ke-n (ton per tahun)

$\mathrm{ST}=$ Total penjualan seluruh tomat oleh pedagang besar di Kabupaten Garut (ton/tahun)

Menurut Pappas (1995) kriteria untuk menentukan struktur pasar adalah:

a. CR8 $<20 \%$ : merupakan pasar yang bersaing dan mendekati model persaingan sempurna

b. $20 \% \leq \mathrm{CR} 8 \leq 80 \%$ : merupakan pasar yang bersaing dan mengarah pada persaingan monopolistik. 
c. CR8 $>80 \%$ : merupakan pasar sangat terkonsentrasi dan cenderung kearah monopoli.

2. Hambatan keluar masuk pasar

Hambatan keluar masuk pasar dapat dihitung dengan Minimum Efficiency Scale (MES) yaitu perhitungan penjualan tomat yang dilakukan oleh pedagang besar terhadap total tomat di Kabupaten Garut. Hambatan masuk dapat dihitung dengan rumus:

$$
\begin{aligned}
E S= & \frac{\text { Penjualan tomat oleh pedagang besar }}{\text { Jumlah tomat di Kabupaten Garut }} \\
& \text { Jika perhitungan menunjukkan }
\end{aligned}
$$

lebih dari 10 persen maka diindikasikan bahwa pemasaran tomat terdapat hambatan masuk.

\section{Analisis Perilaku Pasar}

Metode analisis perilaku pasar dilakukan secara deskriptif kualitataif dengan melihat kegiatan dan aktivitas pemasaran tomat. Perilaku pasar dianalisis dengan mengamati 3 (tiga) fungsi pemasaran yaitu fungsi pertukaran, fisik dan fasilitas yang terjadi pada saluran pemasaran komoditas tomat.

\section{Analisis Kinerja Pasar}

1. Analisis marjin pemasaran

Analisis ini merupakan nilai tambah dari petani hingga sampai di tangan konsumen. Adapun rumus dari marjin pemasaran adalah sebagai berikut:

$$
M T=P r-P f
$$

Keterangan:

MT = Marjin Total

$\operatorname{Pr}=$ Harga tomat di tingkat konsumen $(\mathrm{Rp} / \mathrm{kg})$

Pf = Harga tomat di tingkat petani $(\mathrm{Rp} / \mathrm{Kg})$

\section{Farmer's share}

Analisis ini merupakan persentase harga yang diterima oleh petani dengan harga yang dibayarkan oleh konsumen. Farmer share dapat dihitung dengan rumus:

$$
F S=\frac{P r}{P f} \times 100 \%
$$

Keterangan:

FS $=$ Persentase yang diterima petani

$\operatorname{Pr}=$ Harga tomat di tingkat konsumen $(\mathrm{Rp} / \mathrm{kg})$

Pf $=$ Harga tomat di tingkat petani $(\mathrm{Rp} / \mathrm{Kg})$

\section{HASIL DAN PEMBAHASAN}

\section{Struktur Pasar}

1. Konsentrasi pasar

Konsentrasi pasar dianalisis dengan Eight Firm Concentration Ratio (CR 8) dengan membandingkan volume penjualan tomat segar dengan total penjualan komoditas tomat di Kabupaten 
Garut. Hasil analisis didapatkan penjualan tomat 8 pedagang terbesar di Kabupaten Garut mencapai 24.648 ton/tahun dan jumlah produksi tomat di Kabupaten Garut tahun 2018 mencapai 114.426 ton/tahun.

Perhitungan hasil penelitian didapatkan konsentrasi rasio delapan (8) pedagang adalah terkonsentrasi lemah dengan nilai $21,54 \%$. Nilai ini berarti delapan (8) pedagang tidak menguasai secara menyeluruh tetapi mengarah pada kondisi pasar persaingan monopolistic. Hal ini disebabkan pasar memiliki banyak pedagang dan memberikan peningkatan persaingan antara produsen untuk menjual kepada konsumen.

\section{Hambatan masuk pasar}

Hambatan masuk pasar dilakukan untuk melihat pesaing yang muncul dan mencoba masuk ke dalam pasar, merebut bagian dari pangsa pasar. Penelitian menghasilkan $21,5 \%$ dan disimpulkan adanya hambatan masuk karena MES menunjukkan perhitungan lebih dari 10 persen. Hal ini diindikasikan bahwa pemasaran tomat di Kabupaten Garut terdapat hambatan masuk. Hambatan masuk disebabkan oleh karena setiap pelaku usaha harus memiliki modal yang besar, harus mempunyai akses kepada pedagang pasar, penguasaan informasi pasar, serta kepercayaan diantara pemberi modal kepada penerima modal.

\section{Perilaku Pasar}

Perilaku pasar adalah aktivitas yang terjadi di pasar dan erat kaitannya dengan struktur maupun kinerja pasar. Kohls dan Downey (1972) membagi 3 fungsi pemasaran, yaitu fungsi pertukaran (pembelian dan penjualan), fisik (pengangkutan, penyimpanan, dan pemrosesan), dan fasilitas (sortasi, grading, informasi harga, penyediaan dana, dan penanganan risiko). Fungsifungsi pemasaran pada lembaga pemasaran komoditas tomat dapat dilihat pada Tabel 1.

Fungsi pemasaran akan dilakukan oleh setiap lembaga pemasaran yang menjalankan. Adapun lembaga pemasaran tersebut diantarannya:

a. Petani

Penjualan hasil panen dilakukan oleh petani berbeda-beda tergantung dari hasil panen yang dimiliki. Petani dengan lahan kecil biasanya menjualnya ke pedagang pengumpul atau pedagang besar di sekitar desa atau kecamatan, sedangkan petani dengan lahan yang luas biasanya menjualnya langsung ke Pasar Induk. Petani yang menjual tomat 
kepada pedagang pengumpul/besar biasanya melakukan transaksi di kebun kemudian hasil panen diangkut ke gudang pedagang tanpa adanya sortasi dan grading, tetapi jika petani tersebut menjualnya langsung ke pasar induk, proses sortasi dan grading dilakukan. Petani terjadang mengetahui perkembangan harga sehingga mempunyai daya tawar, namun jika dilihat risiko produk yang cepat busuk maka terkadang petani menjual sesuai harga pasar.

b. Pedagang pengumpul dan pedagang besar

Pedagang pengumpul dan besar mempunyai peran untuk membeli tomat dari petani dan menjualnya ke pedagang pasar induk, industri atau supermarket. Pedagang pengumpul dan besar selalu melakukan fungsi sortasi, grading dan mengemas tomat dijual, untuk menambah harga tomat tersebut. Informasi pasar sangat diketahui secara baik. Kadang-kadang transaksi dilakukan antara petani dan pedagang dengan perjanjian pembayaran tempo 1 hingga 2 hari, tetapi ada juga pedagang yang membayarnya secara cash terhadap petani.

c. Pedagang pasar induk
Pedagang pasar induk merupakan pedagang yang menampung hasil panen tomat di wilayah sentra konsumsi antara lain di wilayah Jakarta, Tangerang, Bekasi, Bogor, Pontianak, Bangka Belitung, Surabaya. Pedagang pasar induk merupakan pusat informasi perubahan harga tomat, dimana pasokan semua tomat berkumpul di pasar induk dari semua daerah sentra produksi terdekat, sehingga apabila pasokan sudah terlihat banyak maka pedagang secara otomatis menurunkan harga, apabila pasokan yang datang dari wilayah produksi tomat mulai berkurang maka penwaran harga tomatpun akan naik. Pedagang pasar induk memiliki beban biaya tenaga kerja bongkar muat peti tomat dari truck dan biaya sewa kios. Tomat ketika sudah sampai di pasar induk langsung dijual dan punya resiko tak terjual jika terjadi kelebihan pasokan.

d. Pedagang Ecer dan Supermarket

Pedagang ecer merupakan lembaga pemasaran yang memiliki fungsi menjual tomat tehadap konsumen langsung. Biasanya harga tomat di pedagang pengecer dan supermarket memiliki keuntungan yang lebih tinggi karena risiko tidak laku dan busuk ada pada pedagang pengecer. 
Tabel 1. Fungsi-fungsi Pemasaran

\begin{tabular}{|c|c|c|c|c|c|c|c|}
\hline \multirow{3}{*}{$\begin{array}{c}\text { No } \\
1\end{array}$} & \multicolumn{2}{|c|}{ Fungsi-fungsi Pemasaran } & \multirow{3}{*}{$\begin{array}{c}\text { Petani } \\
- \\
\sqrt{ }\end{array}$} & \multirow{3}{*}{$\begin{array}{c}\text { Pedagang } \\
\text { Pengumpul }\end{array}$} & \multirow{3}{*}{$\begin{array}{c}\begin{array}{c}\text { Pedagang } \\
\text { Besar }\end{array} \\
\sqrt{ } \\
\sqrt{ }\end{array}$} & \multirow{3}{*}{$\begin{array}{c}\text { Pedagang } \\
\text { Pasar } \\
\text { Induk } \\
\sqrt{ } \\
\sqrt{ }\end{array}$} & \multirow{3}{*}{$\begin{array}{c}\begin{array}{c}\text { Pedagang } \\
\text { Ecer }\end{array} \\
\sqrt{ } \\
\sqrt{ }\end{array}$} \\
\hline & & a. Beli & & & & & \\
\hline & Pertukaran & b. Jual & & & & & \\
\hline \multirow{3}{*}{2} & \multirow{3}{*}{ Fisik } & a. Angkut & $\sqrt{ }$ & $\sqrt{ }$ & $\sqrt{ }$ & - & $\sqrt{ }$ \\
\hline & & b. Simpan & - & - & $*$ & $\sqrt{ }$ & - \\
\hline & & c. Proses & - & - & - & - & - \\
\hline \multirow{6}{*}{3} & \multirow{6}{*}{ Fasilitas } & a. $\quad$ Sortasi & * & $\sqrt{ }$ & $\sqrt{ }$ & - & - \\
\hline & & b. Grading & $*$ & $\sqrt{ }$ & $\sqrt{ }$ & - & - \\
\hline & & c. Informasi & & & & & \\
\hline & & Harga & $*$ & $\sqrt{ }$ & $\sqrt{ }$ & $\sqrt{ }$ & $\sqrt{ }$ \\
\hline & & d. Dana & $\sqrt{ }$ & $*$ & $\sqrt{ }$ & - & $\sqrt{ }$ \\
\hline & & e. Risiko & $\sqrt{ }$ & $*$ & $*$ & $\sqrt{ }$ & $\sqrt{ }$ \\
\hline
\end{tabular}

Keterangan: $\sqrt{ }=$ Sering, $*$ = Kadang-kadang, $-=$ Tidak Pernah

\section{Kinerja Pasar}

Pada komoditas tomat di Kabupaten Garut ini rantai pasarnya menghubungkan petani dan konsumen dengan melewati pedagang pengumpul, pedagang besar, pedagang luar pulau, pasar induk, pedagang pengecer dan supermarket. Pelaku-pelaku dalam saluran pemasaran tersebut, kadang kala perannya merangkap, misalnya petani merangkap menjadi pengepul atau pedagang besar merangkap menjadi supplier supermarket.

Banyaknya saluran pemasaran yang terjadi dalam proses pemasaran tomat di Kabupaten Garut adalah sebagai berikut :

1. Petani - Pedagang Pengumpul Pedagang Besar - Pedagang Pasar Induk - Pedagang pengecer Konsumen
2. Petani - Pedagang besar - Pedagang luar pulau - pedagang pasar induk pedagang pengecer - konsumen.

3. Petani - Pedagang Besar- Pedagang Pasar Induk - Pedagang Ecer Konsumen.

4. Petani - Pedagang Besar - Supplier Supermarket - Supermarket Konsumen.

5. Petani - Pedagang Besar - Industri Pengolahan.

6. Petani - Pedagang Pasar Induk Pedagang pengecer.

\section{Margin pemasaran dan Farmer's share}

Analisis marjin pemasaran merupakan perhitungan yang digunakan untuk dapat melihat biaya dan keuntungan dari setiap aktivitas lembaga pemasaran yang berperan aktif. Beberapa hal yang dapat membedakan besarnya marjin pemasaran antara lain adalah 
saluran pemasaran yang dilalui, jumlah tomat yang dipasarkan, jarak petani dengan konsumen, panjang saluran pemasaran yang dilalui, sistem pembayaran, biaya pemasaran, keuntungan serta harga yang diperoleh petani (Rian, 2014).

Biaya pemasaran dikeluarkan oleh setiap lembaga pemasaran dalam melakukan aktifitas pemasarannya, biaya akan mempengaruhi besarnya marjin an mempengaruhi besarnya marjin pemasaran dan profit marjin (Awaliyah \& Saefudin, 2020). Beberapa biaya yang dikeluarkan oleh pelaku tergantung dari beberapa hal yang dilakukan. Petani mengeluarkan biaya budidaya dan terkadang mengeluarkan biaya transportasi apabila tomat langsung dipasarkan ke pasar induk. Pedagang pengumpul mengeluarkan biaya untuk biaya angkut hasil panen dari kebun ke gudang. Pedagang besar biasanya mengeluarkan biaya untuk proses sortir, grading, pengepakan, transportasi, penyusutan sarana dan prasarana serta biaya penyusutan.

Pedagang luar pulau mengeluarkan biaya bongkar muat pelabuhan, transportasi kapal laut, serta pergudangan menggunakan cool storage pada proses penyimpanan. Pedagang pengecer biasanya mengeluarkan biaya untuk transportasi saja ketika tomat di beli dari pasar induk kabupaten setempat.

Total marjin pemasaran tertinggi terjadi pada saluran pemasaran luar pulau dimana margin pemasarannnya mencapai $\mathrm{Rp}$ 10.000,00 dan marjin pemasaran terendah terjadi pada saluran pemasaran. untuk industri yaitu sebesar Rp 2.500,00 Rincian biaya untuk menghitung margin pemasaran tersebut bisa dilihat pada Tabel 2.

Melihat perhitungan farmers share pada tabel 2 menunjukkan rasio antara harga di tingkat petani terhadap harga di tingkat pengecer. Pada penelitian ini memperlihatkan bahwa share tertinggi yang didapatkan petani terjadi pada saat petani menjual tomat kepada pedagang besar untuk kebutuhan industri yaitu dengan share senilai $67 \%$, hal ini terjadi karena rantai pemasaran yang pendek terjadi pada saluran ini, dan penetapan harga jual biasanya di atas harga pasar karena bersifat kontrak. Sedangkan share terendah terjadi yaitu ketika petani menjual tomatnya ke pedagang besar untuk didistribusikan ke luar pulau yaitu $25 \%$, hal tersebut terjadi karena panjangnya saluran pemasaran dan jauhnya pasar yang tuju. 
Tabel 2. Perhitungan analisis margin pemasaran dan farmer's share

\begin{tabular}{|c|c|c|c|c|c|c|c|c|c|c|c|}
\hline \multirow[t]{2}{*}{ No } & \multirow{2}{*}{$\begin{array}{l}\text { Pelaku Saluran } \\
\text { Pemasaran }\end{array}$} & \multicolumn{2}{|c|}{ Pasar Induk } & \multicolumn{2}{|c|}{$\begin{array}{l}\text { Pasar Luar } \\
\text { Pulau }\end{array}$} & \multicolumn{2}{|c|}{ Industri } & \multicolumn{2}{|c|}{ Supermarket } & \multicolumn{2}{|c|}{$\begin{array}{l}\text { Pedagang } \\
\text { pengecer }\end{array}$} \\
\hline & & Harga & Share & Harga & Share & Harga & Share & Harga & Share & Harga & Share \\
\hline \multirow[t]{4}{*}{1} & Petani & & $35 \%$ & & $25 \%$ & & $67 \%$ & & $35 \%$ & & $55 \%$ \\
\hline & Total Biaya & 2.500 & $64 \%$ & 2.500 & $39 \%$ & 2.500 & $63 \%$ & 2.500 & $47 \%$ & 2.800 & $85 \%$ \\
\hline & Profit margin & 1.000 & $16 \%$ & 2.500 & $18 \%$ & 2.500 & $71 \%$ & 2.000 & $26 \%$ & 2.700 & $40 \%$ \\
\hline & Harga jual & 3.500 & & 5.000 & & 5.000 & & 4.500 & & 5.500 & \\
\hline \multirow[t]{5}{*}{2} & Pedagang Pengumpul & & & & & & & & & & \\
\hline & Total Biaya & 100 & $3 \%$ & & & & & & & & \\
\hline & Profit margin & 400 & $7 \%$ & & & & & & & & \\
\hline & Margin Pemasaran & 500 & & & & & & & & & \\
\hline & Harga Jual & 4.000 & & & & & & & & & \\
\hline \multirow[t]{5}{*}{3} & Pedagang besar & & & & & & & & & & \\
\hline & Total Biaya & 800 & $21 \%$ & 1.050 & $16 \%$ & 1.500 & $38 \%$ & 1.800 & $34 \%$ & & \\
\hline & Profit margin & 700 & $11 \%$ & 1.950 & $14 \%$ & 1.000 & $29 \%$ & 1.700 & $22 \%$ & & \\
\hline & Margin Pemasaran & 1.300 & & 3.000 & & 2.500 & & 3.500 & & & \\
\hline & Harga jual & 5.500 & & 8.000 & & 7.500 & & 8.000 & & & \\
\hline \multirow[t]{5}{*}{4} & $\begin{array}{l}\text { Pedagang Pasar Luar } \\
\text { Pulau }\end{array}$ & & & & & & & & & & \\
\hline & Total biaya & & & 2.600 & $40 \%$ & & & & & & \\
\hline & Profit margin & & & 2.400 & $18 \%$ & & & & & & \\
\hline & Margin Pemasaran & & & 5.000 & & & & & & & \\
\hline & Harga jual & & & 13.000 & & & & & & & \\
\hline \multirow[t]{5}{*}{5} & Pedagang pasar induk & & & & & & & & & & \\
\hline & Total Biaya & 400 & $10 \%$ & 200 & $3 \%$ & & & & & 400 & $12 \%$ \\
\hline & Profit margin & 1.100 & $18 \%$ & 1.900 & $14 \%$ & & & & & 1.100 & $16 \%$ \\
\hline & Margin pemasaran & 1.500 & & 2.300 & & & & & & 1.500 & \\
\hline & Harga jual & 7.000 & & 15.300 & & - & & - & & 7.000 & \\
\hline \multirow[t]{10}{*}{6} & $\begin{array}{l}\text { Pedagang } \\
\text { pengecer/supermarket }\end{array}$ & & & & & & & & & & \\
\hline & Total biaya & 100 & $3 \%$ & 100 & $2 \%$ & & & 1.000 & $19 \%$ & 100 & $3 \%$ \\
\hline & Profit margin & 2.900 & $48 \%$ & 4.900 & $36 \%$ & & & 4.000 & $52 \%$ & 2.900 & $43 \%$ \\
\hline & Margin pemasaran & 3.000 & & 4.700 & & & & 5.000 & & 3.000 & \\
\hline & Harga jual & 10.000 & & 20.000 & & & & 13.000 & & 10.000 & \\
\hline & Harga beli konsumen & 10.000 & & 20.000 & & 7.500 & & 13.000 & & 10.000 & \\
\hline & Total Biaya & 3.900 & $100 \%$ & 6.450 & $100 \%$ & 4.000 & $100 \%$ & 5.300 & $100 \%$ & 3.300 & $100 \%$ \\
\hline & Total Keuntungan & 6.100 & $100 \%$ & 13.650 & $100 \%$ & 3.500 & $100 \%$ & 7.700 & $100 \%$ & 6.700 & $100 \%$ \\
\hline & Total marjin & 6.300 & $0 \%$ & 10.000 & $0 \%$ & 2.500 & $0 \%$ & 8.500 & $0 \%$ & 4.500 & $0 \%$ \\
\hline & Efisiensi pemasaran & 0,39 & & 0,32 & & 0,53 & & 0,41 & & 0,33 & \\
\hline
\end{tabular}

Sumber : Data primer, diolah

\section{KESIMPULAN DAN SARAN}

\section{Kesimpulan}

Kesimpulan dari hasi penelitian menunjukkan bahwa rasio penjualan 8 pedagang tomat besar terkonsentrasi lemah yang mengarah pada persaingan monopolistik. Terdapat hambatan masuk pasar komoditas tomat ini. Perilaku pasar menunjukkan, aktivitas pemasaran paling banyak dilakukan adalah aktivitas jual, beli, angkut dan pemanfaatan informasi harga sesama pelaku pemasaran. Aktivitas sortasi dan grading mayoritas hanya dilakukan oleh para pedagang 
pengumpul dan besar. Penangana resiko pemasaran terbesar terjadi di petani dan pedagang pengecer. Analisis margin pemasaran memperlihatkan, margin pemasaran tertinggi terjadi ketika tomat dijual untuk tujuan pasar luar pulau, dan margin pemasaran terendah terjadi ketika tomat dipasarkan untuk tujuan kebutuhan industri. Hasil analisis farmer's share menunjukkan, share tertinggi yang diterima petani adalah ketika menjual tomatnya untuk kebutuhan industri, hal ini terjadi karena pendeknya rantai pemasaran dan harga jual untuk industri bersifat kontrak di atas harga pasar.

\section{Saran}

Saran sebaiknya petani melakukan proses sortasi dan grading supaya bisa menambah keuntungan.

\section{UCAPAN TERIMA KASIH}

Penulis mengucapkan terimakasih kepada Kemenristekdikti atas pelaksanaan Penelitian Dosen Pemula tahun 2020.

\section{DAFTAR PUSTAKA}

Awaliyah, F., \& Saefudin, B. R. 2020. Efisiensi Pemasaran Komoditas Mangga gedong Gincu di Kabupaten Cirebon. Jurnal Paradigma Agribisnis 3(April), 1-11.
Badan Pusat Statistik. 2016. Produksi Tanaman Sayuran (Buncis, Bayam, Ketimun dan Tomat) Menurut Kabupaten/Kota di Provinsi Jawa Barat Tahun 2016. Jakarta BPS.

Badan Pusat Statistik. 2018. Statistik Tanaman Sayuran dan Buahbuahan Semusim Indonesia. Jakarta. Badan Pusat Statistik.

Fadli, Iqbal. Kesal dihargai Rp 200 per $\mathrm{kg}$, petani Garut buang tomatnya di jalanhttps:/www.merdeka.com/peri stiwa/kesal-dihargai-rp-200-per-kgpetani-garut-buangtomatnya-dijalan.html. 2015.

Irawan B. Fluktuasi Harga, Transmisi Harga, dan Marjin Pemasaran Sayuran dan Buah. 2007. Jurnal Analisis Kebijakan Pertanian. Vol 5(4): 358-373.

Jaya WK. 2001. Ekonomi Industri. Yogyakarta (ID): Fakultas Ekonomi. Universitas Gajah Mada.

Kohls, Richard L dan David Downey. 1972. Marketing of Agricultural Product, Macmillan Publishing Co., Inc. New York.

Marina, Ida, Dety Sumawati. 2017. Model Produksi Tomat di Sentra Produksi Kabupaten Garut. Jurnal Ilmu Pertanian dan Peternakan. Vol 5 (2) : 147-155.. 4.

Oke Finanace. Harga Tomat di Cianjur Tembus Rp20 Ribu/Kg. https://economy.okezone.com/read/ 2016/04/22/320/1369965/hargatomat-di-cianjurtembus-rp20-ribu$\mathrm{kg} .20163$.

Pappas James, L dan Mark Hirschey, 1995. Ekonomi Managerial. Bina Rupa Aksara Jakarta.

R. Pamungkas, Rian. 2014. Efisiensi Pemasaran Komoditas Durian Asal Kecamatan Kemranjen Kabupaten Banyumas. Skripsi. Universitas Jenderal Soedirman. Purwokert0. 